extensive gravel-pits are worked, as at Beeston and Sawley. The pebbles and small boulders found in the gravels are very similar to those found in the drift, of which some detached portions may be seen at New Basford, Lenton, Cinder Hill, and Annesley. In these instances the drift lies immediately upon the Bunter Sandstone. They are all in the Leen basin; and supposing them to be of Post-glacial age, they would seem to indicate a comparatively recent date (speaking geologically) for the present valley of that river, which is certainly formed by the erosion of the Bunter, on which the drift lies in elevated positions. The abundance of Bunter pebbles at present scattered over the Permian strata in the Leen Valley affords corroborative evidence of this former extension of the Bunter strata. The age of the Valley of the Trent is not so easily made out. From the occurrence of drift on the higher portions of ground included within its present basin, it would appear that the sculpturing of the main features of the landscape began during, or before the Glacial Epoch. Great, however, as is the amount of alluvium and low-level gravel contained in the present valley, there can be little doubt that this is now the redeposited drift, since bones of recent Mammalia have been found in the river valley; notably in the sinking of the Wilford Pit, where they lay at the very bottom of the alluvial deposits, 25 feet below the surface. If, as it has been supposed, the Trent was once a tributary of the Rhine, that will only carry us back (according to Prof. Ramsay) to Miocene times. The question then arises whether the time between that and the Drift period is sufficient to allow for the denudation of the present area of Trent drainage, and the contemporaneous cutting down of the two passages through the Oolite escarpment, one of which is now occupied by the Humber, the other by the Witham at Lincoln.

\title{
NOTICHS OF MFMOIRS.
}

I.-Mineralogicax Observations in the Argentine Republic. Mineralogische Beobachtungen im Gebiete der argentinischen Republik von Alfred Stelzner. Mit chemischen Beiträgen von Max Siewert. Mineralogische Mittheilungen, 1873, Heft iv. pp. 219-254.

T $\mathrm{N}$ this paper Dr. Stelzner, of Cordoba, records the results of his mineralogical studies in certain parts of the Argentine Republic. The value of the communication is much increased by the analytical work contributed by Dr. Siewert.

The Sierra of Cordoba, which stretches in a north and south direction over nearly three degrees of latitude, is formed of three parallel ridges, of which the central and most lofty, called the Sierra Alta, rises to a height of about 1200 metres above the surrounding pampas. These mountains consist essentially of crystalline slates, associated with granite and other rocks. The granite is penetrated in many places by quartz-stocks, which are interesting for the sake of the accessory minerals they carry. Although consisting mainly of quartz, they invariably contain mica and large crystals of orthoclase; and may thus represent a highly quartziferous variety of pegmatite. 
Beryl occurs in fine crystals, in some cases measuring $10 \mathrm{c.m}$. in diameter and $30 \mathrm{c.} \mathrm{m}$. in length; whilst apatite is found in similar, though much smaller, green crystals. Stelzner has discovered triplite-a phosphate of iron and manganese-in two varieties, the one light and the other dark coloured; the former represents the purer and fresher condition of the mineral. Analyses of both varieties are published by Siewert. The alteration of triplite has given rise to heterosite. Near San Roque Stelzner has discovered the rare mineral Columbite, specimens of which have also been analysed. Some interesting questions are suggested by the paragenesis of the minerals in these quartz-stocks, and their relation to similar occurrences elsewhere.

Alternating with the old crystalline schists of the Sierra are certain zones of crystalline limestone, which have been specially studied by Stelzner. As accessory minerals in these limestones, he mentions quartz, orthoclase, hornblende, magnesia.mica, titanite, garnet, pistacite, coccolite, scapolite, wollastonite, chondrodite, serpentine, ceylanite, calcite, and malachite. The description of these minerals is followed by an interesting discussion of their probable origin, with special reference to the development of mineral silicates in metamorphic limestones.

The third part of Stelzner's paper describes the enargite lodes of the Famatina Mountains. A mineral associated with the enargite is described as a new species under the name of Famatinite. From Siewert's analysis it appears to be a combination of the sulphides of copper, antimony, and arsenic; in fact, an antimonial enargite, in which part of the antimony is replaced by arsenic. Its composition may be represented by the following formula: $4\left(3 \mathrm{Cu}_{2} \mathrm{~S} . \mathrm{Sb}_{2} \mathrm{~S}_{5}\right)+$ $\left(3 \mathrm{Cu}_{2} \mathrm{~S} . \mathrm{As}_{2} \mathrm{~S}_{5}\right)$.

After describing the occurrence of a number of other minerals, more or less rare, Dr. Stelzner calls attention to certain sandstones exhibiting curious pseudomorphs after rock-salt. Some blocks of this stone have the surface studded with small hemispherical protuberances, believed to be pseudomorphs after a peculiar form of saline efflorescence. The layer of sandstone immediately above this surface would necessarily show pits corresponding with these elevations, and resembling those little hollows which in many sandstones represent rain-drops. Without denying that such impressions may be preserved under peculiarly favourable conditions, Stelzner raises the question whether some of the so-called "fossil rain-drops" may not be merely the concavities corresponding with pseudomorphs after an efflorescence of salt.

F. W. R.

2.-Ueber die Bedeutung von Tiefbohrungen in Der BergöLzone Gatiziens. By Fr. Julius Notr. Jahrbuch der $k$. $k$. Geologischen Reichsanstalt, Jahrgang 1873, Band xxiii. No. 1, pp. 1-8, with 2 plates of sections.

TTHE district in Galicia over which signs of mineral oil occur is 1 said to be sixty miles (German) long, by an average of two to three wide, occupying a great part of the northern branch of the Carpathian Mountains. 


\section{Notices of Memoirs-E. Tietze-Geology of the Karst.}

From several shafts, not over 100 feet deep, as much as 3,000 cwt. of mineral oil have been taken. Volatile gases are a danger in sinking shafts; a spark struck from the tool will sometimes cause an explosion with fatal results, and cause the sinking to be abandoned: the gas is described as sometimes issuing from the pores of permeable sandstone with a loud hissing sound. In Middle Galicia, the most important locality for mineral oil is the neighbourhood of Dukla and Ropianka. Here 150 shafts have been sunk, and the yearly produce is about 20,000 cwt. The Ropianka oil appears of a dark-green colour, or by transmitted light brownish-red; its specific gravity is 0.81 to 0.83 ; it contains paraffin. From one bore-hole of about 300 feet deep, as much as 4,000 cwt. were obtained. The American system of rope-boring seems to be much used, but it is said to be useless for anything over 500 feet. Different qualities of oildiffering in composition-may occur in the same shaft, showing that there must be several sources, met with at different levels it may be, not in connexion with one another.

The place of largest production in Galicia is Boreslaw, where in all 6,000 shafts have been sunk, mostly shallow ones, 98 feet to 180 feet, from which $90,000 \mathrm{cwt}$. of oil and 45,000 cwt. of hydrocarbon of a waxy consistence have been taken. The total amount raised in Galicia in the last few years is estimated at $300,000 \mathrm{cwt}$., and its value, when refined, at $£ 300,000$. The author recommends that the State should undertake certain deep borings, as they seem to have done in the Coal-districts of Upper Silesia and Bohemia, with results very favourable to the prosperity of large districts. He thinks that the oil industry would be very largely increased thereby. At present the native supply is not sufficient for the wants of the population, and American petroleum is therefore imported. $\quad$ E. B. T.

3.-Geologische Darstellung der Gegend zwisghen Carlstalt in Croatien und dem nördlichen Theil des Canals der MorLACCA. By E. Tretze. Jahrbuch der $k$. k. Geologischen Reichsanstalt, Jahrgang 1873, Band xxiii. No. 1, pp. 27-70.

1 HE author of this report was cornmissioned to examine the above district at the instance of the military authorities in charge of the frontier, who experienced the greatest inconvenience from the great dearth of water in the district. This sketch does not extend over the whole of the "Karst," or that Limestone and Dolomite range which extends from Carinthia and Istria, through Western Croatia, Dalmatia, and Albania, to Greece, on the eastern shore of the Adriatic; but it deals with a small piece of its length, but of the full breadtb, taken out of the middle. The Croatian "Karst" is, speaking broadly, a grand saddle in a N.W. and S.E. direction of 'Triassic rooks, accompanied with Cretaceous beds on the flanks, and including many minor undulations. Similar petrological character and scarcity of fossils make it frequently impossible to distinguish the ages of the various Dolomites.

The oldest beds in the district are some dark-grey, reddish, or violet Dolomites near Ogulin; they are sandy and very tough beds,

DECADE II, - VOL, I, - NO, VII. 


\section{Notices of Memoirs-E. Tietze-Geology of the Karst.}

and gave much trouble to engineers of tunnels on the railway. They are probably of "Wellenkalk" (Muschelkalk) age. Above these are black limestones, in which no fossils have been found, but which represent probably a higher stage in the Muschelkalk. As far as appearance yoes, these are said to be easily mistakable for Lias or certain Cretaceous beds. Other grey or whitish thick limestones, forming the tops of many mountains, and even ranges, are referred to the Upper Trias; there is often a dolomitic breccia at the base of these. The Dolomites on the coast near Zengg have been referred by Stoliczka to the Cretaceous, but by Foetterle to the Trias. 'The Foraminifera, which the former thought he had found, are said by Fr. von Hauer to be too dubious. The present author, in the absence of fossils, is unable to decide definitely between the views of his predecessors; but he inclines to consider them Trias. In the neighbourhood of Zengg is some porphyritic Diorite, which may probably be of Triassic age.

The Lias has been known for some length of time to occur near Carlstalt; the fossils from here, determined by Schlœnbach, were Upper Lias forms, Ammonites bifrons, etc. No fossils of other Lias horizons have yet been found in this lccality.

Other beds, viz. those at the summit of the Stallak and Vinica, have been referred provisionally to the Jurassic, but no fossils have been found in either case.

The Cretaceous beds occur chiefly on the eastern side of the saddle. Near Ogulin were found Radiolites abundantly, with Pecten, Nerinaa, etc.; again near Carlstalt, small Caprotince. Petrologically these differ from the Triassic limestones generally in being less tough.

The next higher beds are the Nummulitic-whitish-yellow limestones. Brown and greenish sandstones of the Upper Eocene fill up the middle of the valley, the fruitfulness of which soil is in strong contrast to the barrenness of the surrounding districts.

Near Bribir occurs some Lignite in the latest Tertiary or Quaternary beds. Mastodon angustidens (Cuv.), Tapirus priscus (Kaup), and Cervus sp., were described from here by Hörnes in 1848.

There remains still the characteristic "terra rossa," or red loam, the origin of which has given rise to discussion. Our author is opposed to its being considered a marine formation, and he notices that it does not occur in the sandstone districts-it seems to be connected with the limestone. As yet no fossil remains have been found in it. He connects it with the hollowing out of the caverns, and refers its formation to the latest Tertiary period immediately before the Glacial epoch.

With respect to the hydrographic relations of the district, the case seems simply this:-the limestone is so cut up by clefts and cavities that no rain can give rise to a system of streams, it all disappears through the rock-fissures which communicate below ground. The subterranean erosion must be immense. Near Ogulin the R. Dobra disappears below ground, but further east, near Popovosello, the other side of the mountain, it emerges again into daylight. This is similar to the disappearance of the R. Poik in the Adelsberg cavern 
These subterranean rivers are very characteristic of the "Karst" district, being numerous here, though of course they occur elsewhere.

Another feature of the district are the periodical lakes, e.g. the Zirkinitz lake. In these cases after prolonged rain, or melting of snow, the plain will be covered with water; this is no mere overflowing, the water does not come off the hills merely,-it comes mostly from below, either directly from clefts or welling up through gravel. Our author explains the rise of water through the damming back of the water from overfilled subterranean channels. The description of the so-called "Doline" corresponds exactly with the "swallow-holes" of N. England; they are said to be very numerous in the Karst.

The great absence of springs of water has caused this district to be called the "stony Arabia of Austria." The inhabitants are mostly obliged to rely on rain water collected in ponds, and sometimes have to drive their cattle three hours to water. The parts covered with luxuriant forest are just as devoid of springs as the rest of the district, so that no mere planting would do any good. Artesian wells are impracticable, owing to the fissured state of the limestone. In fact it is recommended to form proper reservoirs for retaining the rain water; of which there is a good supply, the annual fall being 4.42 cubic feet to the square foot of area on an average. E. B. T.

\section{4.-Geologische Uebersicithskarte DeR GSthrReichisohungar-} ischen Monarchie. Blatt 8. Siebendurgen. By Franz Ritter voN HaUER. Jahrbuch der k. k. Geologischen Reichsanstalt, Jahrgang 1873, Band xxiii. No. 1, pp. 71-115.

TTHE explanation of Sheet 8 is divided into three parts, the three 1 mountain systems which surround Siebenburgen (Transylvania) being described separately.

1. The Carpathians. - Crystalline schists are found in the Bukowina, etc., both micaceous and chloritic, and with quartzites. Some beds that were formerly placed in this eategory have been shown to be Trias.

Of sedimentary formations the oldest is the Dyas (Permian), consisting of quartz conglomerates and quartzites. These were formerly mapped as Greywacké. Of the Trias the lower division is represented by fossiliferous beds over 2,000 feet thick, and referred to the Werfen shales and Guttenstein Limestone (Muschelkalk). The Upper Trias is represented by various Dolomites and by Red Marble, with Ammonites Metternichii and globose species, probably of Hallstadt age, as well as by shales with Halobia. The Lower Lias is found near Kronstadt, and contains coal-beds; then come shales with Belemnites paxillosus; furtber the red Adneth beds (Upper Lias) with numerous Ammonites occur.

Of the Oolitic rocks some of the upper stages, viz. beds with fossils similar to those of the Stramberg horizon. Of the Cretaceous several divisons occur. Lower Neocomian, shales and limestones with Aptychus; Upper Neocomian; Upper Chalk, and Marls with Beleminitla mucronata. 
Fruptive rocks occur, melaphyre, porphyrite, etc.

One colour is used for the Carpathian sandstone. It is not attempted to divide it into Cretaceous and Eocene divisions; the Nummulitic beds, however, are separately mapped: the conglomerates connected with the Eocene are desoribed as many thousands of feet thick.

The varieties of Trachytic eruptive rocks of Eocene age seem to be numerous.

\section{The Southern Transylvanian and Banat Mountains.}

The crystalline rocks are represented by mica schist and gneiss, for whioh one colour is used, hornblende and chlorite schists being frequently intercalated. In one district eruptive quartz-porphyry has broken through these; in one place granite is in contact with Permian strata, at another it contains pieces of sedimentary rock, which seem to be carboniferous, and give a post-carboniferous age to the eruption. Again, Neocomian Limestones have been altered by contact with the granite, showing that the granite is here newer than the Lower Cretaceous beds.

Besides the granite, there are porphyry and tuffs of Cretaceous age, the latter containing Cretaceous plants.

Of sedimentary rocks in this district we have Carboniferous shales, limestones and sandstones, with Crinoids, Corals, and Plants, a coarse conglomerate being at the base. The Permian exists as greywacké with some red shale, and has trap-ashes connected with it. Fossils have been found, the plants indicate the existence of two or three horizons. The Trias may be present, but details are wanting to enable it to be separately mapped. The Lias is an important formation, from the considerableiCoal-bed which it bears in the. Steyerdorf district. Both Lower and Middle Lias are present.

The sandstone between two of the Coal-beds has yielded a rich fossil flora; the age is probably Am. planorbis zone of Lower Lias. Jurassic beds are present, the A. Murchisone zone of the Inferior Oolite, probably some of the higher zones, and even the Bath Oolite. At Swinitza the Oolites, though rich in Ammonites, are only six feet thick altogether.

The Upper Oolite is represented, but its divisions are not sufficiently worked out. Of the Lower Cretaceous some beds are referred to the L. Neocomian and considered to be the age of the Berrias beds, others to the Aptien, viz. Upper beds at Rossfeld. The Upper Neocomian is also shown by beds with Rudistes and Caprotina. The Upper Cretaceous is represented by beds of the Gosau type, and by beds with Exogyra columba (Cenomanien).

The Eocene occupies a very much smaller area in the Banat than in the other districts east and west of Siebenburgen. The newer Tertiaries are represented in the Schylthal by coal-bearing beds; fossils show them to be of the age of the freshwater Molasse (Miocene). In the neighbourhood of Dobra the Cerithium beds of the Miocene occur.

3. The Mountains of the Western Transylvania Boundary.

The crystalline rocks are represented by mica schist, gneiss, and 
clayslates, the schistose group occupying a larger area by far than the massive crystalline rocks, granites, Diorites, etc.

The eruptive rocks are numerous; red porphyries occur in the Dyas and Trias distriots. Lias beds liave been altered in one case, here the eruption would be probably of Jurassic age; Augiteporphyry, Melaphyr, and Syenite (the latter eruptive through Lias) occur. The trachytic rocks are present in three groups, viz. Propylite (Dacite and Greenstone Trachyte), Trachyte proper (Andesite), and Rhyolite: Their eruption took place in newer Tertiary times.

Of the sedimentary rocks the Carboniferous are the oldest in this district. The Permian (Dyas) is probably present; the separation between it and the Trias being indistinct. The Muschelkalk is probably represented by limestones and Dolomites, but no fossils have been found. The oldest fossils are those of the Lias, but there are no Coal-beds in Lias beds in this district. Oolitic beds are foundthe Cretaceous are largely developed: The Rossfeld beds (L. Neocomian) contain Amm. cryptoceras; above the Caprotina limestone, beds with Gosau fossils occur.

The Eocene rocks are thick and cover a large area. Stache has separated them into three groups, viz. Lower Eocene, freshwater mostly, Chara seeds, Palidina, etc. Middle Eocene, marls with Nummulina perforata, limestones with $N$. lovigata, and gypsumbearing beds. Upper Eocene, includes beds which may be of $L$. Miocene (Aquitanien) age.

Newer Tertiary beds, - the three stages of the Vienna Tertiaries occur, the Marine, the Sarmatic, and the Congeria beds, but they are not always separately mapped.

The paper ends with a few words on the Transylvania midland district, which is entirely newer Tertiary or Quaternary.-E. B. T.

\section{5.-Brief Aibstracts.}

1.-Beitraege zur Kenntiss fossilfer Binnentaunen. By Theodor FUös. Jahrbuch der k. k. Geologischen Reichsanstalt, Jahrgang 1873, Band xxiii. No. 1, pp. 19-26, with 2. plates of fossils..

$\mathrm{T}$ this paper some new species from the Vienna Tertiaries are 1 described and figured; they are as follows:

\begin{tabular}{l|l} 
From the Congeria Beds. \\
Melanopsis avellana. \\
$\begin{array}{l}\text { obsoleta. } \\
\text { Sturii. }\end{array}$ \\
\hline Melania Lotocho.
\end{tabular} \mid $\begin{aligned} & \text { Gardium Neumayeri. } \\
& \text { Karreri. }\end{aligned}$

Turbo Aningeri.

From the Sarmatic Stage. Melania sutwata.

2.-Jones, Prof. T. R. Flint: its Nature, Character, and Adaptability for Implements. Reliquia Aquitanica, parts xiv., xv., pp. 202,205 . 4to. [1874.]

Flint, in one condition or another, is found in most calcareous 
rocks. It ocours as sheets and as nodules, generally in beds. It is homogeneous and consists of silica, not so pure, however, as is the case with quartz. This silica, once in solution, has been accumulated round sponges, etc., changing some of the surrounding chalk into its own substance.

Flint has yielded fit material for fashioning into tools or weapons, the application of blows and pressure producing sharp flakes, the substance is also capable of being dressed into definite shapes.

The surfaces of broken flints suffer changes from exposure and from moisiure, becoming opaque, and often shining when affected by alkaline water.

The note concludes with a list of the chief works relating to the subject.

W. W.

3.-Lowe, W. B. Geological Section [Report of ]. Rep. Rugby

School of Nat. Hist. Soc. for 1872, pp. 47-49 (2 plates). [1873.]

Notes the occurrence of the rare Discina Holdeni in the Lias at Hillmorton Pits, of bones in various later deposits, and of various other fossils. Gives a section of Drift over Lias at Rugby Pit, and sections of gravel, etc, along a sewer in Hillmorton and Clifton Roads. A detailed account of the section at the Victoria Lime Works to a depth of 72 feet, through Lias clay and stone, is also given in plate vi.

W. W.

4.-Salter, J. W. A Catalogue of the Cambrian and Silurian Fossils in the Geological Museum of the University of Cambridge. With a Preface by the Rev. Prof. A. Sedgwick, and a Table of Genera, etc., by Prof. J. Monnis. 4to. pp. xlviii. and 204. Cambridge, [1873].

The greater part of the long preface is taken up with an account of the Cambro-Silurian controversy, in which Prof. Sedgwick fully states his own views and their history.

This is followed by a Table of the Classification of the Lower Palæozoic rocks according to Sedgwick, Murchison, Jukes, Lyell, Phillips, and the Geological Survey. Prof. Morris contributes a summary of the contents of the Catalogue, and a Table of the Range of the Genera.

The Catalogue is illustrated by woodents and arranged stratigraphically, beginning with the lowest beds. An elaborate geological map (woodcut) of Portmadoc Estuary, with a multitude of faults, is given at p. 9. There are many paragraphs on the stratigraphical relations of the beds, etc.

W. W.

\footnotetext{
REVIEW

I.-Geognostische Karte Der Umgegend von Heidelbirg. Bearbeitet von Dr. E. W. Benecke und Dr. E. C. Comen. Blatt II. Sinsherm. Strassburg: Karl J. Trübner, 1874.

7 THIS second part of a very elaborate map of the geological features of that portion of the Grand-Duchy of Baden which lies to the traveller's immediate left hand during a railway journey from
} 